\title{
RADIATION EXPOSURE OF ANAESTHETISTS
}

\author{
W. D. KYLE, M.D.*
}

THERE Is much general concern today over the increased use of radiation and its effect on the total population, as well as on medical persomnel. This particular study is an attempt to assess the risk to anaesthetists, who are administering more and more to patients undergoing diagnostic and therapeutic radiologic procedures.

The general problem and risks involved have been reviewed by Kincaid ${ }^{1}$ and Dornette $^{2}$ among others. However, no reports have appeared that attempt actually' to measure the total radiation recelived by anaesthetists over a period of time in the routine course of their work. The radiation dosage to diagnostic $X^{4}$-ray workers has been measured by Osborne ${ }^{3}$ and Ardran, ${ }^{4}$ but this is not too relevant. Recently Keen ${ }^{5}$ has reported measurements of radiation by monitoring devices in various areas of operating rooms, but these are isolated readings and noncumulative in nature.

This particular study is an effort to measure the radiation absorbed by all members of the Department of Anaesthesia in a fairly large teaching hospital over a period of months, for the purpose of assessing whether or not dangerous levels of radiation exposure were being reached,

\section{Properties OF X-RAYS}

Any standard physics textbook will afford a good review of the properties of $\mathrm{X}$-rays, but a brief review here should describe those properties that give rise to radiation hazard. X-rays are the energy phenomenon resulting when a stream of electrons strikes certain metals. The metal then radiates one form of electromagnetic wave, called $\mathrm{X}$-ray. When $\mathrm{X}$-rays are absorbed by a body, electrons are displaced from atoms, and this results in ionization and subsequent chemical change. It is this resulting ionization, particularly in living tissue, that gives rise to harmful biological effects loosely termed "radiation damage."

$\mathrm{X}$-rays travel in a straight line, can scatter in various directions from matter on which they impinge, and their intensity varies inversely as the square of the distance from the source. These properties are important in any discussion of dosages, exposures, and protection from radiation. Of course in this atomic age X-rays are not the only form of ionizing radiation to which anaesthetists may be exposed. Cobalt- 60 and radium emit harmful gamma rays, while other radioactive substances may emit alpha and beta rays.

\section{General Considerations}

The harmful effect of all this radiation to man is twofold: somatic and genetic. The somatic effect represents that cumulative damage to the individual in his

${ }^{*}$ Department of Anaesthesia, University Hospital, Edmonton, Alberta. 
lifetime, while the genetic effect represents possible chromosomal changes in gonadal cells only apparent in future generations. The mechanism is the same for both. The ionization produced by radiation absorption within the atoms of the living cell may disorganize the cell enzyme systems causing cell death, proliferation, neoplasm, or chromosomal alterations.

Two concepts must always be borne in mind. First, the area of absorption is important: that is, the same dose on a small area is far more dangerous than when widely spread. And, second, the time of absorption is also important: that is, a dose that might be fatal if absorbed instantly might be tolerated if absorbed over a long period of time.

\section{Units of Measurement}

Radiation is measured by the number of ions produced in air per unit of time by the energy absorbed by irradiated material; or, with a radioactive source, by the actual number of disintegrations per second. The roentgen is a measure of the dose of $\mathrm{X}$ or gamma radiation in air. The term rad is correctly used to indicate a unit of absorbed dose of any ionizing radiation. One rad is 100 ergs per gram. One roentgen of exposure will usually produce one rad of absorbed dose in soft tissue. The rem is a unit of absorbed dose that takes into account the relative biological effectiveness of different types of radiation, such as alpha rays, beta rays, and electron streams. For X-rays, one rad equals one rem. The term curie is the unit commonly used with radioactive sources.

\section{AllowaBles}

The International Commission on Radiological Protection has set forth a "maximum permissible weekly dose" for whole-body exposure for occupationally exposed workers. This is $0.3 \mathrm{rad}$ weekly, but the dose should not exceed 5 rads per year. ${ }^{6}$

\section{Methods of Measurement}

All methods utilize the effects that result from the release of energy by $\mathrm{X}$-ray absorption.

1. The erythema method crudely measures the amount of radiation required to produce reddening of the skin.

2. The "pastille dose" method utilizes the energy required to turn barium platinocyanide from yellow to brown. This is also inaccurate.

3 . The discharge chamber, in which a charged electrode sits in a nonconductive air cell, is also used. When X-rays pass through the chamber, the air is ionized and allows the charge to be conducted. The dissipation of the charge by radiation may be measured on an electrometer and thus the $\mathrm{X}$-ray dosage determined.

4. The blackening of photographic film is also used as an indicator of X-ray radiation. This is the commonly used method in X-ray departments of hospitals. After development, the relative blackening of the film is measured by the degree of light transmission through a photocell. A check whereby part of the film is shielded to eliminate certain frequencies, of wave is essential. 


\section{HARMFUL EFFECTS}

As discussed by Kiernan, ${ }^{7}$ somatic effects may be temporary or permanent, local or generalized. These local effects include skin and subcutaneous reactions, bone and cartilage necrosis, and the development of neoplasms. General body effects may include haemopoetic tissue depression, sterility, epilation, skin atrophy, as well as an increased incidence of leukaemia and cancers of the thyroid, skin, and bone. However, these are always after very high dosage. The study of the genetic effects of radiation is extraordinarily complex. It should be noted that although mutations have been produced in animals, no scientific study has proved a linear relationship of dose to genetic effect in humans.

\section{INVESTIGATION AND METHOD}

In this series the photographic film discoloration method was used to measure the radiation. Each member of the Departhnent of Anaesthesia wore one of the standard badges as supplied by the Department of Radiology, affixed to the anterior chest area of his operating room clothing. These were worn at all times, and changed weekly, when they were measured by technicians in the Radioactive Laboratory of the hospital. No attempt was made to avoid exposure, with the anaesthetist staying in his customary position at all times.

Each anaesthetist recorded the date and type of procedure when X-ray or radioactive material was used in conjunction with anaesthesia. This was carried on for five months by the staff of eight.

\section{Results}

During the five-month period of investigation a total of 195 cases in which radiation was encountered were recorded. This was 6 per cent of the total number of anaesthetics administered in this period, exclusive of maternity cases.

Throughout the several months that the badges were worn only two were recorded as having exposures of over $40 \mathrm{mrad}$ in any two-week period, and these were only $50 \mathrm{mrad}$ readings. This was well within the allowables as stated by the International Commission on Radiological Protection.

The chief radiologist of the hospital reported that "these exposures were not considered sufficient to warrant either continuation of the wearing of the badges routinely, or to suggest any changes in the precautions taken by the anaesthetists."

\section{Summary and Conclusions}

In the light of the present interest in the dangers of radiation, which is briefly reviewed, an attempt has been made to measure the radiation absorbed by anaesthetists in their routine practice. If one accepts the method of measurement as fairly accurate, and also accepts the relative use of X-rays in conjunction with anaesthesia in our hospital as typical, then it seems safe to assume that anaesthetists have no cause for alarm, and need take no special precautions at present. The results are well within present-day permissible levels. 
RÉSUMÉ

Etant donné l'appréhension actuelle des risques de radiation, nous avons entrepris cette étude pour essayer de déterminer le risque que courent les anesthésistes qui, au cours de leur travail de routine, sont de plus en plus|exposés aux rayons-X.

Comme résultat de l'exposition aux rayons- $X$, c'est l'ionisation des tíssus qui s'ensuit, et c'est cela qui engendre les effets muisibles qui peuvent être soit somatiques, soit génétiques.

La Commission Internationale de la Protection Radiologique a fixé comme dose hebdomadaire maxima permise pour l'exposition de l'organisme complet: 0.3 de rad; la dose annuelle" ne doit pas dépasser 5 rad.

Au cours de cette êtude, les huit anesthésistes d'un service d'anesthésie ont porté une insigne ordinaire de détection de radiation, type film photographique, pendant leur travail habituel et, cela, durant cinq mois. Ils n'ont pas essayé d'éviter les radiations. Les insignes ont été changées à toutes les semaines, et le degré de radiation déterminé par le service de radiologie. Aucune lecture n'a dépassé les doses permises.

D'après nos résultats, il appert que le danger de radiation, dans les conditioṇs ordinaires, n'existe pas pour les anesthésistes et que ceux-ci, au cours de leur travail quotidien, n'ont pas à prendre de précautions spéciales pour se protéger contre la radiation des rayons- $\mathrm{X}$.

\section{REFERENCES}

1. Kincaid, O. W' The Problem of Repeated Exposure to Radiation by Anesthetists. Anesth. \& Analg. 37: 361 (1958).

2. Donnette, W. H. L. \& OTT, T. Radiation Safety for the Anesthesiologist. Anesth. \& Analg. 37: 167 (1958).

3. Osborn, S. Radiation Doses Received by Diagnostic X-ray Workers. Brit. J. Radiol, 28: 650 (1955).

4. Ardran, G. M.; Crooks, H. E.; Kemp, F. H.; \& Oliver, R. Radiation Dose to the Staff in Medical X-ray Department. Brit. J. Radiol. 30: 600 (1957).

5. Keen, R. I. The Radiation Hazard to Anaesthetists Brit. J. Anaesth 32: 224 (1960).

6. Her Majesty's Stationery Office, London. Code of Practice for the Protection of Persons Exposed to Ionizing Radiations (1957).

7. Kiernan, M. K. Radiation, Health and Safety. The- Winnipeg Clinic Quarterly 13: 10 (1960). 